\title{
Kirurgi tryggere enn stenting ved carotisstenose
}

\author{
Kirurgisk endarterektomi gir lavere \\ komplikasjonsrisiko enn stentbe- \\ handling ved carotisstenose.
}

Flere tidligere studier har vist at kirurgisk endarterektomi reduserer risikoen for hjerneslag ved symptomgivende carotisstenose. De senere år har en rekke internasjonale sentre tatt $\mathrm{i}$ bruk stenting som alternativ til kirurgi, til tross for mangelfull dokumentasjon. Nå foreligger to artikler med foreløpige resultater fra en randomisert multisenterstudie der man sammenlikner kirurgi $(\mathrm{n}=858)$ og stentbehandling $(\mathrm{n}=855)$ ved carotisstenose $(1,2)$. Hovedstudiens primære endepunkt vil først kunne evalueres etter tre år, men interimanalysen etter 120 dager viser at forekomst av hjer- neslag, død eller prosedyrerelatert hjerteinfarkt er signifikant høyere etter stenting enn etter kirurgi $(8,5 \%$ versus $5,2 \%$, $\mathrm{p}=0,006$ ).

- Studien vil bli tillagt stor vekt, da den er solid gjennomført. Man har savnet store randomiserte undersøkelser, sier overlege Christian Lund ved Nevrologisk avdeling, Oslo universitetssykehus. Det er godt samsvar mellom de kliniske og nevroradiologiske funnene. Diffusjonsvektet cerebral MR indikerer at forekomst av nye lesjoner er 3-4 ganger høyere etter stentbehandling. Selve stentprosedyren medfører økt cerebral embolisering.

- Det norske fagmiljøet har foretrukket kirurgisk endarterektomi ved carotisstenose og vil holde fast ved denne praksisen. Stenting bør forbeholdes pasienter der kir- urgi er uegnet, f.eks. strålingsinduserte eller høytsittende stenoser, sier Lund.

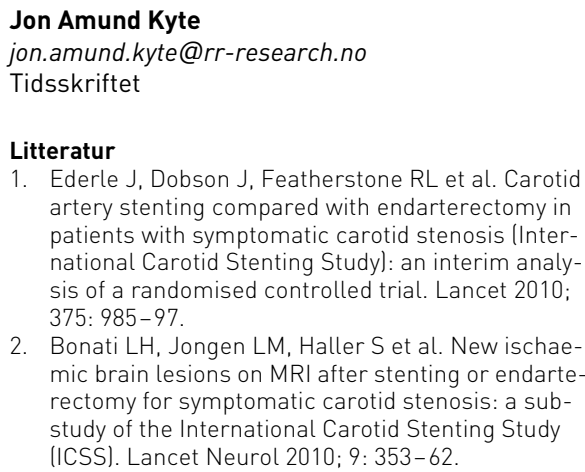

1. Ederle J, Dobson J, Featherstone RL et al. Carotid artery stenting compared with endarterectomy in patients with symptomatic carotid stenosis (International Carotid Stenting Study): an interim analysis of a randomised controlled trial. Lancet 2010; 375: 985-97

2. Bonati LH, Jongen LM, Haller S et al. New ischaemic brain lesions on MRI after stenting or endarterectomy for symptomatic carotid stenosis: a substudy of the International Carotid Stenting Study (ICSS). Lancet Neurol 2010; 9: 353-62.

\section{Ingen blodtrykkssenkende tilleggseffekt av statiner}

Statiners beskyttelse mot hjerte- og karsykdom antas å skyldes endring i lipidprofilen og muligens også antiinflammatoriske og antiproliferative effekter. I tillegg er det forslått at statiner kan senke blodtrykket. Dette har nå vært undersøkt av italienske forskere (BMJ 2010; 340: c1197).

508 pasienter $\mathrm{i}$ alderen $45-70$ år med mild hypertensjon og hyperkolesterolemi ble randomisert til blodtrykkssenkende behandling med og uten pravastatin i tillegg. Studien viste at pravastatin ikke hadde blodtrykkssenkende effekt når det ble gitt til hypertensive pasienter som fikk effektiv hypertensjonsbehandling. Dette tyder på at de beskyttende kardiovaskulære effektene av statiner ikke er avhengig av en blodtrykkssenkende virkning.

\section{Inntak av K-vitamin og antikoagulasjonsbehandling}

Det er velkjent at periodisk inntak av måltider med svært høyt innhold av K-vitamin, f.eks. grønnkål og spinat, kan føre til dysregulering av antikoagulasjonsbehandling. Nå viser en ny studie at svært lavt inntak av K-vitamin også kan være et problem.

Pasient-kontroll-studien omfattet over 1100 pasienter. De som hadde et høyt habituelt K-vitamininntak hadde lavere risiko for å ha subterapeutisk INR-nivå enn dem som spiste kost med normalt K-vitamininnhold. Pasienter med lavt K-vitamininntak til vanlig hadde forhøyet risiko (Br J Haematol 2010; 149: 598-605).

\section{Mammografiscreening virker ikke}

\section{Mammografiscreening ble innført i Danmark med en forventning om $30 \%$ reduksjon i dødelighet av bryst- kreft. Etter 17 år med screening kunne vi ikke påvise noen effekt.}

Screening ble innført i København i 1991 og på Fyn i 1993. I resten av Danmark har det ikke vært noe screeningprogram og heller ikke mye uorganisert screening. De som bor i disse områdene samt kvinner utenom invitert aldersgruppe (50-69 år) er kontrollgrupper. Det tar rundt fem år før man kan se en effekt av screening, og effekten vokser så med tid. Dette skyldes at screening fremskynder diagnosen med flere år, og i tillegg lever folk flere år etter diagnose.

I perioden der screening kunne ha hatt en effekt (1997-2006), falt dødeligheten av brystkreft blant kvinner i alderen 55-74 år med $1 \%$ per år i de screenede områdene, mot $2 \%$ i de ikke-screenede områdene. Blant dem som var for unge til å ha nytte av screening (35-55 år), falt dødelighet av brystkreft med hhv. $5 \%$ og $6 \%$ i screenede og ikke-screenede områder (1).

Mammografiscreening har ikke levd opp til forventningene. Fallet i dødeligheten må skyldes bedre behandling og ikke screening. Alvorlige skadevirkninger, som overdiagnostikk og overbehandling, har dessuten vært undervurdert.

Screeningprogrammet bør revurderes. Evalueringen bør ikke foretas av personer med økono-

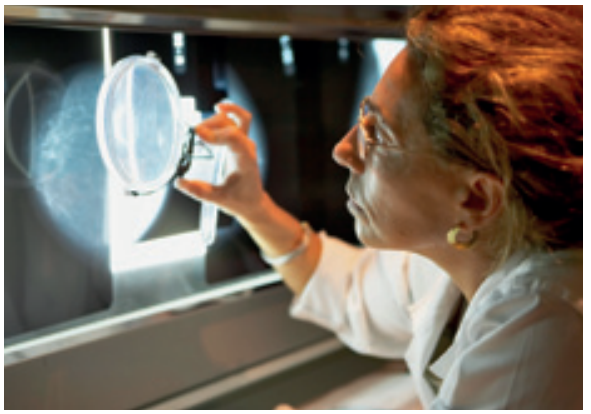

Illustrasjonsfoto (c) Javier Larrea/age fotostock/ GV-Press/NordicPhotos

miske interesser og akademiske karrierer knyttet til screening. Tidligere evalueringer har vært påvirket av slike interessekonflikter. Reduksjonen i dødelighet er blitt overestimert, mens overdiagnostikken er blitt ignorert.

\section{Per-Henrik Zahl}

per-henrik.zahl@fhi.no

Nasjonalt folkehelseinstitutt

\section{Litteratur}

1. Jørgensen KJ, Zahl P-H, Gøtzsche PC. Breast cancer mortality in organised mammography screening in Denmark. A comparative study. BMJ 2010; 340: c1241. 